\title{
A social work study on measuring the impact of gender and marital status on stress: A case study of hydro-power employees
}

\author{
Mohammad Reza Iravani $^{a^{*}}$, Gholamali Iravani ${ }^{\mathrm{b}}$, Akbar Iravani ${ }^{\mathrm{c}}$, Batool Mahmoudi ${ }^{\mathrm{d}}$ and $^{\text {Farzaneh }}$ \\ Salimi $^{\mathbf{d}}$
}

${ }^{a}$ Department of Social Work, Islamic Azad University of Khomeinishahr, Khomeinishahr Branch, Daneshjou Blvd, Iran

${ }^{b}$ Applied and Technical University

${ }^{c}$ PameNoor University, Iran

${ }^{d}$ Secretary of Education, District 4, Esfahan, Iran

\section{A R T I C L E I N F O \\ A B S T R A C T}

Article history:

Received April 15, 2012

Received in Revised form

May, 15, 2012

Accepted 6 June 2012

Available online

June 112012

Keywords:

Stress

Job satisfaction

Employee performance

Working conditions

\begin{abstract}
The study performs an empirical survey to measure the impact of stress among people with various gender and marital status in a hydropower unit located in city of Esfahan, Iran. The study performs the survey among all 81 people who were working for customer service section of this company and consists of two parts, in the first part; we gather all private information such as age, gender, education, job experience, etc. through seven important questions. In the second part of the survey, there were 66 questions, which included all the relevant factors impacting employees' stress. We implement two Levin and t-student tests to see whether gender or marital status has any meaningful influences on creating stress among people. The results indicate that gender has no meaningful impact on creating stress among employees who worked for this hydro plant except difficulty of job conditions. The other findings of this paper is that stress posed from management team had different impacts on employees with various marital status but there were no meaningful differences between married and single couples in terms of other factors posing stress such as unsuitable working conditions, fear of job stability or difficulty of job conditions.
\end{abstract}

\section{Introduction}

Stress is one of preventive factors on employee's efficiency and it can have harmful effects on people's healthcare and personal affairs. Stress can be posed from different working conditions, it may often come from hard working conditions or it may be posed from management teams or employees' supervisors, etc. One primary concern in such circumstances is whether stress has equal impact on women and men or not (Evolahti et al., 2006). It may also have different level of impact between married and single people. Kim et al. (2009) surveyed the moderating roles of organization level and gender in the relationship between job satisfaction and role stress among employees who

* Corresponding author. Tel.: +989130758065

E-mail addresses: iravani@iaukhsh.ac.ir (M. R. Iravani) 
worked for hotel industry. The study measured job satisfaction, role stress in terms of both conflict and ambiguity and demographic information for hotel employees in Republic of Korea. They reported that the effect of role stress on job satisfaction was enormously stronger for female employees and supervisory employees than male and non-supervisory workers.

Literally, there are many factors, which create stress among workers such as the lack of job security, stress created on behalf of management team, etc. Nevertheless, understanding the nature and root of stress in organizations helps us reduce its influence using appropriate methods (Watson et al., 2011; Çekmecelioğlu \& Günsel, 2011). In fact, for many years, there were significant efforts on learning how it is possible to reduce stress among employees (Bassett et al., 1987; Law et al., 1995).

Vearing and Mak (2007) provided another investigation on the joint impact of the big five personality factors and a new model of work stress based on study on effort-reward imbalance (ERI), on employees' depressive symptoms. They reported an association between neuroticism (N) and OVC.

Saastamoinen et al. (2009) examined the own and independent relationships of job strain, workplace bullying, organizational justice and work-home interface with pain. Among women, all psychosocial factors were considered for both acute and chronic pain when adjusted for confounders only. Among men, when adjusted for confounders only, all psychosocial factors were associated with acute and chronic pain, except for family-to-work conflicts among those with acute pain.

Chiang et al. (2010) studied the moderating impacts of job control and work-life balance practices on employee stress in the hotel and catering industry. The results of this survey described that high job demands coupled with low job control and the availability of work-life balance practices leads in a higher level of stress.

Tabatabaei et al. (2011) studied the general health, stress associated to the work and job satisfaction of the Hormozgan Cement Factory employees. The study was semi-experimental with the pre-test and post-test without control group and to improve mental health of employees, psychological trainings and motivational models were executed. The results demonstrated that general health and job satisfaction of employees were higher than average $(\alpha=0.01)$ but their job stress was lower than average $(\alpha=0.01)$. After intervention, results disclosed improvement of job stress and such trainings and models recommended for improvement of employees stress.

Coelho et al. (2011) performed a survey on the mediating impacts of role stress and intrinsic motivation using contextual factors and the creativity of frontline employees. They reported that the creativity of frontline service employees is associated positively with role conflict and negatively with role ambiguity. They performed confirmatory factor analysis of posttraumatic stress symptoms in Brazilian primary care patients using an examination of seven alternative models. Their objective was to study whether the clusters of PTSD symptoms identified in North American and European studies could be replicated in a Brazilian sample composed of 805 primary care patients living in hillside slums. They reported that their results seemed to uphold the cross-cultural validity of the 4factor, first-order model.

Boyas et al. (2012) explained that age, organizational factors are linked with job stress, burnout among child protection workers, and they investigated on how age influences these adverse employee outcomes. They recommended that the paths to job stress, burnout and intent to leave varied by age group. They also concluded that firms needed to establish intervention attempts on younger workers by creating various structures of support, which could help them better deal with the pressures and demands of child protection work.

The present study investigates to find out the important factors influencing job stress in one of Iranian hydro facilities. The structure of this study first explains characteristics of all people who participated in our survey and then reports details of our findings next. 


\section{The proposed study}

The study investigates different factors influencing people to have more stress in a hydropower unit located in city of Esfahan, Iran. Since there were only 81 people working for customer service section of this company and the proposed study tries to focus only on this part of the firm we have decided to distribute questionnaires among all of them. The questionnaire consists of two parts, in the first part, we gather all private information such as age, gender, education, job experience, etc. through seven important questions. In the second part of the survey, there are 52 questions, which include all the important factors influencing employees' stress.

\subsection{Personal characteristics of surveyed people}

We ask 81 employees to take part in this survey, where 73 of them were male and 8 were female. In terms of their educational background, 10 people had only 9 years of educational background, 48 people finished high school and 23 people had colleague education. While 15 people were single, 66 people were married. In terms of employment type, 21 people were permanent employee, 11 people maintained a five-year contract, 44 people had one-year contract and only 5 employee were on temporary contract. In terms of job experience, 20 people aged between 20-29, 36 people aged between 30-39, 15 people were between 40 to 49 and finally, 10 employees were over 50 years of age. In terms of job experience, 45 people has from one to ten years of job experience, 15 people had between 11 to 20 years of job experiences and 21 people has between 21 to 30 years of job experience. Finally, 23 people were regular employee, 14 were workers, 30 people were working in customer service and 14 people were hired as accountants.

\subsection{Methodology}

In this survey, we use two Levin and t-student tests to measure different factors influencing stress. There are 66 questions associated with the proposed study of this survey and our focus in this paper is to see the impact of gender and marital status on stress.

\section{The results}

In this section, we present details of our survey between employees who worked for this hydro generation unit in terms of gender and marital status.

\subsection{Stress between female and male workers}

We first present detailed characteristics of the people who participated in our survey and provided their responses on four types of stress in terms of their gender. As we can observe from the results of Table 1, there were 81 people filled in the questionnaires where 73 were male and the remaining 8 people were female.

\section{Table 1}

Descriptive characteristics of participants in terms of their genders

\begin{tabular}{lllcccl}
\hline & \multirow{2}{*}{ Sub groups } & Gender & \multicolumn{2}{c}{$\begin{array}{c}\text { Degree of freedom } \\
\text { Number }\end{array}$} & Mean & \multicolumn{2}{l}{$\begin{array}{l}\text { Standard } \\
\text { deviation }\end{array}$} & $\begin{array}{l}\text { Standard } \\
\text { error }\end{array}$ \\
\hline 1 & Stress from management and other employees & Male & 73 & 3.20 & 0.804 & 0.096 \\
& & Female & 8 & 2.779 & 0.894 & 0.316 \\
\hline 2 & Difficulty in Job conditions & Male & 73 & 3.545 & 0.831 & 0.0994 \\
& & Female & 8 & 2.769 & 1.019 & 0.360 \\
\hline 3 & Unsuitable working conditions & Male & 73 & 3.100 & 1.098 & 0.131 \\
& & Female & 8 & 2.687 & 0.997 & 0.352 \\
\hline 4 & Fear of job stability & Male & 73 & 3.368 & 0.915 & 0.109 \\
\hline & & Female & 8 & 3.111 & 0.659 & 0.233 \\
\hline & Total & Male & 73 & 3.303 & 0.713 & 0.0853 \\
& & Female & 8 & 2.836 & 0.691 & 0.244 \\
\hline
\end{tabular}


2100

From the results of Table 1, we understand that, on average, men seem to have more stress on behalf of their bosses than women do. Similar results hold for the remaining three sub groups while the gap between female and male is more when we asked them about the stress created from difficulty of job, fear of job stability is the second most important item among men.

Table 2 shows details of our two Levin and t-student tests for the proposed model of this paper. From the results of t-student tests, we can realize that there is no meaningful difference between female and male on different factors creating stress $(\mathrm{P}>0.05)$. In other words, gender does not play an important role on creating stress on employees who worked for this hydro generation unit.

Table 2

The results of Levin test and t-student tests

\begin{tabular}{|c|c|c|c|c|c|c|c|}
\hline \multirow[t]{2}{*}{ Source of stress } & \multirow{2}{*}{$\begin{array}{l}\text { Hypothesis } \\
\text { assumption }\end{array}$} & \multicolumn{2}{|c|}{ Levin test } & \multicolumn{4}{|c|}{ t-student } \\
\hline & & $\mathrm{F}$ & P-value & $\mathrm{t}$ & $\mathrm{df}$ & P-value & Mean-diff \\
\hline \multirow{2}{*}{$\begin{array}{l}\text { Stress from } \\
\text { management and } \\
\text { other employees }\end{array}$} & $\sigma_{1}^{2}=\sigma_{2}^{2}$ & 0.000 & 0.889 & 1.392 & 76 & 0.168 & 0.422 \\
\hline & $\sigma_{1}^{2} \neq \sigma_{2}^{2}$ & - & - & 1.278 & 8.349 & 0.236 & 0.422 \\
\hline \multirow{2}{*}{$\begin{array}{l}\text { Difficulty in Job } \\
\text { conditions }\end{array}$} & $\sigma_{1}^{2}=\sigma_{2}^{2}$ & 1.115 & 0.294 & 2.444 & 76 & 0.017 & 0.776 \\
\hline & $\sigma_{1}^{2} \neq \sigma_{2}^{2}$ & - & - & 2.076 & 8.101 & 0.071 & 0.776 \\
\hline \multirow{2}{*}{$\begin{array}{l}\text { Unsuitable working } \\
\text { conditions }\end{array}$} & $\sigma_{1}^{2}=\sigma_{2}^{2}$ & 0.013 & 0.911 & 1.014 & 76 & 0.314 & 0.412 \\
\hline & $\sigma_{1}^{2} \neq \sigma_{2}^{2}$ & - & - & 1.096 & 9.057 & 0.301 & 0.412 \\
\hline \multirow[t]{2}{*}{ Fear of job stability } & $\sigma_{1}^{2}=\sigma_{2}^{2}$ & 0.912 & 0.343 & 0.770 & 76 & 0.444 & 0.257 \\
\hline & $\sigma_{1}^{2} \neq \sigma_{2}^{2}$ & - & - & 0.999 & 10.372 & 0.341 & 0.257 \\
\hline \multirow[t]{2}{*}{ Total } & $\sigma_{1}^{2}=\sigma_{2}^{2}$ & 0.000 & 1 & 1.758 & 76 & 0.083 & 0.467 \\
\hline & $\sigma_{1}^{2} \neq \sigma_{2}^{2}$ & - & - & 1.803 & 8.793 & 0.106 & 0.467 \\
\hline
\end{tabular}

\subsection{Stress between married and single employees}

In this section, we present our investigation for the effects of marital status on having stress. We

As we can observe from the results of Table 3, there were 81 people filled in the questionnaires where 15 were single and the remaining 66 people were married. From the results of Table 3, we understand that, on average, married people seem to suffer more than single employees do in terms of their job conditions.

Table 3

Descriptive characteristics of participants in terms of their genders

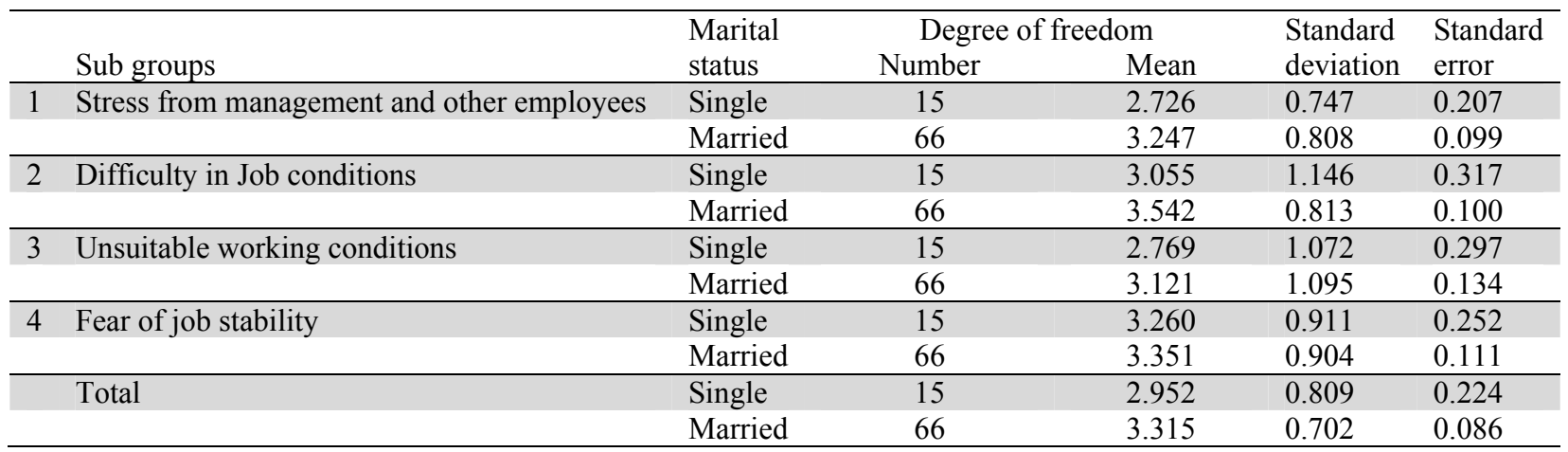


Table 4 shows details of our two Levin and t-student tests for the proposed model of this paper. From the results of t-student tests, we can realize that the meaningful difference is only associated with the first stress item, which is the stress posed from management team towards employees $(t=-2.147$, $\mathrm{P}<0.05)$ but there is no meaningful difference among married and single people for the remaining three items $(\mathrm{P}>0.05)$.

\section{Table 4}

The results of Levin test and t-student tests

\begin{tabular}{|c|c|c|c|c|c|c|c|}
\hline \multirow[t]{2}{*}{ Source of stress } & \multirow{2}{*}{$\begin{array}{l}\text { Hypothesis } \\
\text { assumption }\end{array}$} & \multicolumn{2}{|c|}{ Levin test } & \multicolumn{4}{|c|}{ t-student } \\
\hline & & $\mathrm{F}$ & P-value & $\mathrm{t}$ & $\mathrm{df}$ & P-value & Mean-diff \\
\hline \multirow{2}{*}{$\begin{array}{l}\text { Stress from } \\
\text { management and other } \\
\text { employees }\end{array}$} & $\sigma_{1}^{2}=\sigma_{2}^{2}$ & 0.046 & 0.831 & -2.147 & 77 & 0.035 & -0.520 \\
\hline & $\sigma_{1}^{2} \neq \sigma_{2}^{2}$ & - & - & -2.264 & 17.99 & 0.036 & -0.520 \\
\hline \multirow{2}{*}{$\begin{array}{l}\text { Difficulty in Job } \\
\text { conditions }\end{array}$} & $\sigma_{1}^{2}=\sigma_{2}^{2}$ & 6.046 & 0.016 & -1.837 & 77 & 0.070 & -0.48 \\
\hline & $\sigma_{1}^{2} \neq \sigma_{2}^{2}$ & - & - & -1.460 & 14.47 & 0.166 & -0.48 \\
\hline \multirow{2}{*}{$\begin{array}{l}\text { Unsuitable working } \\
\text { conditions }\end{array}$} & $\sigma_{1}^{2}=\sigma_{2}^{2}$ & 0.042 & 0.838 & 1.062 & 77 & 0.291 & -0.351 \\
\hline & $\sigma_{1}^{2} \neq \sigma_{2}^{2}$ & - & - & -1.078 & 17.30 & 0.296 & -0.351 \\
\hline \multirow[t]{2}{*}{ Fear of job stability } & $\sigma_{1}^{2}=\sigma_{2}^{2}$ & 0.110 & 0.741 & -0.329 & 77 & 0.743 & -0.090 \\
\hline & $\sigma_{1}^{2} \neq \sigma_{2}^{2}$ & - & - & -0.327 & 16.99 & 0.748 & -0.090 \\
\hline \multirow[t]{2}{*}{ Total } & $\sigma_{1}^{2}=\sigma_{2}^{2}$ & 1.620 & 0.207 & -1.658 & 77 & 0.101 & -0.36 \\
\hline & $\sigma_{1}^{2} \neq \sigma_{2}^{2}$ & - & - & -1.507 & 15.76 & 0.152 & -0.36 \\
\hline
\end{tabular}

\section{Conclusion}

In this paper, we have presented an empirical study to measure the effects of stress among people with different personal characteristics in terms of their gender and marital status in a hydropower unit located in city of Esfahan, Iran. We have used two Levin and t-student tests to see whether gender or marital status has any meaningful influences on creating stress among people. The results indicate that gender has no meaningful impact on creating stress among employees who worked for this hydro plant except difficulty of job conditions. The other findings of this paper was that stress posed from management team had different impacts on employees with various marital status but there were no meaningful differences between married and single couples in terms of other factors posing stress such as unsuitable working conditions, fear of job stability or difficulty of job conditions.

\section{Acknowledgment}

The authors would like to thank the anonymous referees for their constructive comments on earlier version of this work.

\section{References}

Bassett, J.R., Marshall, P.M., \& Spillane, R. (1987). The physiological measurement of acute stress (public speaking) in bank employees. International Journal of Psychophysiology, 5(4), 265-273.

Boyas, J., Wind, L. H., \& Kang, S.Y. (2012). Exploring the relationship between employment-based social capital, job stress, burnout, and intent to leave among child protection workers: An agebased path analysis model. Children and Youth Services Review, 34(1), 50-62. 
Chiang, F.F.T., Birtch, T.A., \& Kwong Kwan, H. (2010). The moderating roles of job control and work-life balance practices on employee stress in the hotel and catering industry. International Journal of Hospitality Management, 29(1), 25-32.

Coelho, F., Augusto, M., \& Lages, L.F. (2011). Contextual factors and the creativity of frontline employees: The mediating effects of role stress and intrinsic motivation. Journal of Retailing, 87(1), 31-45.

Çekmecelioğlu, H.G., \& Günsel, A. (2011). Promoting creativity among employees of mature industries: The Effects Of Autonomy And Role Stress On Creative Behaviors And Job Performance. Procedia - Social and Behavioral Sciences, 24, 889-895.

Costa, M.F., Mendlowicz, M.V., Vasconcelos, A.G.G., Berger, W., da Luz, M.P., Figueira, I., Rosa, M.L.G. (2011). Confirmatory factor analysis of posttraumatic stress symptoms in Brazilian primary care patients: An examination of seven alternative models. Journal of Anxiety Disorders, 25(7), 950-963.

Evolahti, A., Hultcrantz, M., \& Collins, A. (2006). Women's work stress and cortisol levels: A longitudinal study of the association between the psychosocial work environment and serum cortisol. Journal of Psychosomatic Research, 61(5), 645-652

Kim, B.P., Murrmann, S.K., \& Lee, G. (2009). Moderating effects of gender and organizational level between role stress and job satisfaction among hotel employees. International Journal of Hospitality Management, 28(4), 612-619.

Law, J., Pearce, P.L., \& Woods, B.A. (1995). Stress and coping in tourist attraction employees. Tourism Management, 16(4), 277-284.

Saastamoinen, P., Laaksonen, M., Leino-Arjas, P., \& Lahelma, E. (2009). Psychosocial risk factors of pain among employees. European Journal of Pain, 13(1), 102-108.

Tabatabaei, S., Hosseinian, S., \& Gharanjiki, B. (2011). General Health, Stress Associated to the Work and Job Satisfaction of Hormozgan Cement Factory Employees in Iran. Procedia - Social and Behavioral Sciences, 30, 1897-1901.

Vearing, A., \& Mak, A. S. (2007). Big five personality and effort-reward imbalance factors in employees' depressive symptoms. Personality and Individual Differences, 43(7), 1744-1755.

Watson, R., Yanhua, C., Ip, M.Y.K., Smith, G.D., Wong, T.K.S., \& Deary, I.J. (2012). The structure of stress: Confirmatory factor analysis of a Chinese version of the stressors in Nursing Students Scale (SINS). Nurse Education Today, In Press. 